\title{
HEMATOLOGICAL AND BIOCHEMICAL BLOOD INDICES OF RAINBOW TROUT DEPENDING ON THE LEVEL OF PROTEIN IN FEEDS
}

V. M. KONDRATYUK, PhD in Agriculture, Associate Professor, P. D. Pshenychnyi Department of Animal Feeding and Feed Technology https://orcid.org/0000-0002-4246-2639

E-mail:vadkondratyk@ukr.net

National University of Life and Environmental Sciences of Ukraine

\begin{abstract}
The article considers the influence of compound feeds with different protein levels on hematological and biochemical parameters of trout blood. The purpose of the experiment was to establish the effect of different protein nutrition levels in commercial rainbow trout feeding on hematological and biochemical parameters of their blood. For this purpose, five experimental groups were formed by the method of analogs. The experiment lasted 210 days and was divided into two periods: equalization (10 days) and main (200 days). During the equalization period, the feeding ration was the same for fish in the control and experimental groups. In the main period, the level of protein in experimental feeds for different experimental trout groups ranged from 44 to $52 \%$ per $1 \mathrm{~kg}$. It was found that different levels of rainbow trout's protein nutrition do not cause significant changes in blood morphological composition. It is proved that rearing trout using compound feeds with a crude protein content of $50 \%$ and $52 \%$ promotes the increase of red blood cells, hemoglobin, white blood cells and phagocytic activity in blood. The use of $44 \%$ and $46 \%$ low crude protein diets in fish feeding reduces the morphological components in blood. As a result of studies on the phagocytic activity of neutrophils in fish blood, a slight increase was revealed under the influence of the studied factor. The analysis of the obtained results showed that with increasing levels of crude protein in the diets of rainbow trout, the concentration of total protein and its fractions in blood serum increased. Accordingly, the amount of total protein in blood of fish in the control group was $60.0 \mathrm{~g} / \mathrm{L}$, in the experimental groups - it was within the range of 59.6-65.3 $\mathrm{g} / \mathrm{L}$. The increase in the level of rainbow trout's protein nutrition in the experimental groups 4 and 5 caused an increase in the number of albumins, b-globulins and $\gamma$-globulins compared to control. As a result of experimental studies, an increase in the mineral status of rainbow trout blood during use of feeds with the crude protein content of 50-52\% was established. No differences were found during the assessment of trout white blood cell counts.
\end{abstract}

Keywords: commercial rainbow trout, fish feeding, compound feeds, protein, hematological parameters, leukocyte formula, blood biochemical indices 


\section{Introduction.}

Many researchers confirm the need for hematological studies to clarify the physiological status of fish because using physiological methods it is possible to establish the presence of pathological disorders in a particular system and to identify the degree and nature of deviations from the normal fish body's status. Also, a significant number of researchers emphasize the great practical importance of studying blood parameters in different species of fish depending on the growing conditions. Therefore, the study of changes in the blood system of rainbow trout fish depending on protein nutrition is one of the criteria to assess the course of adaptive and compensatory reactions. Thus, the study of different rainbow trout protein nutrition levels' impact on hematological and biochemical parameters is necessary to determine the protein need for fish in order to ensure the successful operation of cold-water fish farms in Ukraine.

\section{Analysis of recent researches and publications.}

Biologically complete protein nutrition is one of the main conditions that determine the efficacy of feed nutrients, productivity, health and reproductive functions of fish.

The generalization of modern research in the field of fish nutrition taking into account their species, breed and age characteristics, as well as the issue of efficient use of protein feeds and supplements is a necessary condition for solving the problem of protein in industrial fish breeding.

Analysis of fish blood based on appropriate biochemical research methods is one of the main stages of monitoring the feeding full value condition. However, the variety of factors, including technological, that can affect the blood biochemical composition, laboratory diagnostic methods, the lack of perfect differential diagnostic programs, especially in the conditions of changing nutritional parameters within the physiological norm, significantly complicate the interpretation of data and assessment of fish protein nutrition full value (Sherman et al., 2002; Karabulut \& Yandi, 2010).

Biochemical studies of rainbow trout blood permit expansion of the understanding of the relationships between blood parameters and mechanisms of homeostasis regulation and to accumulate data for summarizing them at the level of reference values.

It is known that the main component of cells and tissues in the animal body are proteins, which are associated with all vital functions. Their content in feed affects the level of fish productivity and economic efficiency of production. Accordingly, biochemical blood tests can detail the signs of possible abnormalities. Protein deficiency in the diet is known to be accompanied by certain changes in nitrogen compound metabolism, in particular, a decrease in the serum total protein content mainly due to albumin and sometimes $\alpha$ - and $\beta$-globulins and residual nitrogen.

An unbalanced protein diet disrupts the synthesis of proteins, enzymes, hormones and fixation of biologically active substances, which requires the blood test study of general clinical and biochemical parameters along with specific criteria in assessing full value condition of feeding (Kim \& Kaushik, 1992; Ullah-Khan et al., 2019).

Equally important are the hematological parameters in trout, as blood is one of the most reactive tissues of 
the fish body. With the help of morpho-physiological analysis of blood and its physicochemical properties, it is possible to accurately and objectively assess the condition of the fish body. Species features of blood are hereditary. These include the composition and morphology of cell forms, quantitative parameters and their seasonal and age dynamics (Mahmud et al., 1996).

\section{Materials and methods.}

Experimental studies on Oncorhynchus mykiss (Walbaum, 1792) two-yearold rainbow trout were carried out in the "Shipot" farm, Perechyn district of Transcarpathian region.

The purpose of the research and economic experiment was to establish the effect of different commercial rainbow trout's protein nutrition levels on hematological and biochemical parameters in their blood.

For this purpose, five experimental groups were formed by the method of analogs (Table 1). During the equalization period of the experiment, which lasted 10 days, the feeding ration was the same for fish in the control and experimental groups. In the main period of the experiment ( 200 days), the protein level in the feed of trout from the experimental groups was regulated by changing the individual components in the feed (using combined mathematical methods to optimize the calculation by the Agro Soft Win Opti software).

Rainbow trout were fed 4-6 times a day during the experimental period, at regular intervals during the day. The required amount of feed was calculated according to the indices of individual fish weight and ambient temperature at the time of feeding.

Weighing of experimental trout was performed once every 10 days using electronic scales in a calibrated water-logged container with an accuracy of $0.1 \mathrm{~g}$. The rearing of commercial two-year-old rainbow trout was carried out in ponds with an area of $100 \mathrm{~m}^{2}$ at the stocking density of $50 \mathrm{fish} / \mathrm{m}^{2}$, and the water level in them of $1 \mathrm{~m}$. The total number of trout in experimental studies was 25 thousand fish. The conditions of experimental fish keeping met the regulatory requirements in salmon farming (Kanydev, 1985; SOU-05.01-37-385:2006).

Blood samples were collected from the heart using an injection needle inserted from the abdomen along the sagittal line between the pectoral fins. Heparin was used as an anticoagulant.

The concentration of red blood cells was determined by in vitro method using a storage solution, a microscope and a Goryaev's chamber, white blood

\section{Design of the research and economic experiment}

\begin{tabular}{|c|c|c|c|c|}
\hline \multirow{3}{*}{ Fish group } & \multirow{3}{*}{$\begin{array}{c}\text { Stocking density } \\
\text { at the beginning } \\
\text { of the experiment, } \\
\text { fish } / \mathrm{m}^{2}\end{array}$} & \multirow{3}{*}{$\begin{array}{l}\text { Mean body } \\
\text { weight at the } \\
\text { beginning of the } \\
\text { experiment, } g\end{array}$} & \multicolumn{2}{|c|}{ Experimental periods } \\
\hline & & & equalization (10 days) & main (200 days) \\
\hline & & & \multicolumn{2}{|c|}{ protein content per $1 \mathrm{~kg}$ of feed, $\%$} \\
\hline 1 - control & 50 & $55.3 \pm 2.48$ & \multirow{5}{*}{48} & 48 \\
\hline 2 - experimental & 50 & $56.1 \pm 2.13$ & & 44 \\
\hline 3 - experimental & 50 & $54.8 \pm 2.37$ & & 46 \\
\hline 4 - experimental & 50 & $55.1 \pm 3.13$ & & 50 \\
\hline 5 - experimental & 50 & $54.5 \pm 2.99$ & & 52 \\
\hline
\end{tabular}


cells - by an indirect method on a blood smear, hemoglobin - by a hemoglobin cyanide method with a spectrometer. In addition, the total serum protein was determined refractometrically (Kondrakhin et al., 2004; Vlizlo et al., 2012).

Indices of constructive metabolism, namely: glucose content in the fish blood was determined by the method of Kondrakhin et al. (2004). The principle of the method is based on the ability of glucose oxidase, while oxidizing, to form a complex compound that turns the solution pink. The color intensity of the solution is proportional to the glucose content in the sample. The blood glucose concentration was calculated according to a standard solution in $\mathrm{mmol} / \mathrm{L}$. The content of total protein in blood plasma was determined using sets of reagents from "Lachema" (Czech Republic) and standard solutions of substrates.

The research results were processed by the method of variation statistics (Plokhynskyi, 1969) using the STATISTICA 7.0. and MS Excel software using built-in statistical functions.

\section{Results of the research and their discussion.}

Characterizing various changes in the body's vital activities, the blood composition permits to reflect the characteristic properties of metabolism at different stag- es of the development and under different conditions of the body's existence.

Blood cells are the first in the body to respond to abiotic and biotic environmental factors, they are easily redistributed, thus ensuring the development of adaptive and immune responses.

The results of the studied feeding factor's influence on the hematopoiesis status in the rainbow trout fish body are shown in Table 2.

The results of our studies indicate that different levels of rainbow trout's protein nutrition do not cause significant changes in blood morphological composition.

It was found that rearing trout on feed with a crude protein content of $50 \%$ (experimental group 4) and $52 \%$ (experimental group 5) leads to an increase in blood red blood cells, hemoglobin, white blood cells and phagocytic activity, while the use of fish diets with low crude protein content (experimental groups 2 and 3) leads to reduced morphological components of the blood. Thus, the number of red blood cells in fish of these groups was within the range of $1.16-1.18 \mathrm{~T} / \mathrm{L}$, which is by $5.1 \%$ and $3.3 \%$ less compared to the control index. The hemoglobin content was also lower by $9.1 \%$ and $5.2 \%$ than in the control. The above difference is statistically significant $(p<0.01$ and $p<0.05)$.

Similar nature of changes was observed in rainbow trout according to

\section{Hematological parameters in rainbow trout, $n=5$}

\begin{tabular}{|l|c|c|c|c|c|}
\hline \multirow{2}{*}{\multicolumn{1}{|c|}{ Index }} & \multicolumn{5}{|c|}{ Fish group } \\
\cline { 2 - 6 } & 1st & 2nd & 3rd & 4th & 5th \\
\hline Red blood cells, T/L & $1.22 \pm 0.07$ & $1.16 \pm 0.05$ & $1.18 \pm 0.05$ & $1.28 \pm 0.09$ & $1.31 \pm 0.08$ \\
\hline Hemoglobin, g/L & $122 \pm 1.33$ & $111 \pm 2.09^{* *}$ & $116 \pm 1.97^{*}$ & $123 \pm 2.01$ & $125 \pm 2.10$ \\
\hline White blood cells, g/L & $22.9 \pm 0.09$ & $21.6 \pm 0.11$ & $22.0 \pm 0.12$ & $23.5 \pm 0.08$ & $24.01 \pm 0.21^{* *}$ \\
\hline Phagocytic activity, \% & $45.8 \pm 2.31$ & $42.3 \pm 2.12$ & $44.5 \pm 2.54$ & $46.8 \pm 2.63$ & $47.3 \pm 2.41$ \\
\hline
\end{tabular}

Note. ${ }^{*} \mathrm{p}<0.05 ;{ }^{*} \mathrm{p}<0.01-$ compared to group 1. 
the number of white blood cells in the blood, which in fish of the control group was $22.9 \mathrm{~g} / \mathrm{L}$, and the experimental groups ranged from 21.6 to $24.1 \mathrm{~g} / \mathrm{L}$. There is no significant difference in this index between the control and experimental groups.

Considering the changes in the phagocytic activity of neutrophils in the blood of experimental fish, there is a slight increase under the influence of the studied factor.

Phagocytic activity of neutrophils in the blood of fish in experimental group 5 was higher compared to the control and was $47.3 \%$ vs. $45.8 \%$. And when fish consumed feed with a crude protein content of $46 \%$ (group 3) and $50 \%$ (group 4), the phagocytic activity index was at the control level.

Thus, rearing the rainbow trout on compound feeds with different levels of crude protein did not significantly change their morphological components in blood. However, there is a slight positive effect of crude protein on the number of red blood cells, hemoglobin and phagocytic activity of neutrophils. The above difference between the analogues of the experimental groups was within physiological fluctuations.

Depending on the level of crude protein in feeds consumed by rainbow trout, certain fluctuations were found in blood biochemical parameters (Table 3 ) but for most of them, no significant differences were found.

The above data show that with increasing levels of crude protein in the diets of rainbow trout, the concentration of total protein and its fractions in blood serum increased. Thus, the amount of total protein in blood of fish from the control group was $60.0 \mathrm{~g} / \mathrm{L}$, in the analogs from the experimental groups, this figure was within the range of 59.6-65.3 g/L.
The increase in the feed of crude protein to $52 \%$ provided the highest level of the total protein in blood: in fish of experimental group 5, it significantly exceeded the value in the control group by $5.3 \%(\mathrm{p}<0.05)$. In this case, there is also a probable increase in the total protein concentration and compared to trout, which received in the feed $50 \%$ of crude protein: the total protein amount in blood serum of fish in the experimental group 4 compared to the analogs of the experimental groups 2 and 3 , was higher by $5.03 \%$ and $4.2 \%$, respectively, and the control group index was probably lower by $4.3 \%$.

The level of total protein in blood serum of trout in the experimental groups 2 and 3 approached the control index, and was $59.6 \mathrm{~g} / \mathrm{L}$ and $60.1 \mathrm{~g} / \mathrm{L}$ against $60.0 \mathrm{~g} / \mathrm{L}$, respectively.

The study of the blood protein fractional composition in rainbow trout groups, which were fed compound feeds with different levels of crude protein, minor changes were also found. Thus, the increase in the level of protein nutrition in rainbow trout of experimental groups 4 and 5 caused an increase in the number of albumins, $\beta$-globulins and $\gamma$-globulins, compared to similar indices of fish in the control group.

It was also found that rearing fish on feed with a reduced crude protein content of up to $44 \%$ (experimental group 2 ) and $46 \%$ (experimental group 3 ) did not significantly affect the changes in the fractional composition of blood proteins.

Similar patterns were observed for the activity of enzymes, which varied depending on the studied factor. Thus, feeding rainbow trout compound feeds with a crude protein content of 50-52\% (experimental groups 4 and 5) showed higher alanine aminotransferase activity by $10.0 \%(\mathrm{p}<0.05)$ and $26.1 \%$ 


\section{Blood biochemical parameters in rainbow trout of the experimental groups, $n=5$}

\begin{tabular}{|l|c|c|c|c|c|}
\hline \multirow{2}{*}{ Index } & \multicolumn{5}{|c|}{ Fish group } \\
\cline { 2 - 6 } & 1 st & 2nd & 3rd & 4th & 5 th \\
\hline Total protein, g/L & $60.0 \pm 1.68$ & $59.6 \pm 1.65$ & $60.1 \pm 1.71$ & $62.6 \pm 1.82$ & $65.3 \pm 1.45^{*}$ \\
\hline Albumins, g/L & $24.5 \pm 1.06$ & $23.8 \pm 1.14$ & $24.0 \pm 2.04$ & $24.9 \pm 2.13$ & $26.3 \pm 1.88$ \\
\hline Globulins, g/L & $35.2 \pm 1.17$ & $34.9 \pm 1.24$ & $35.1 \pm 1.36$ & $37.8 \pm 1.47$ & $38.1 \pm 1.35$ \\
\hline$\alpha$-globulins & $11.8 \pm 0.95$ & $11.3 \pm 0.96$ & $12.0 \pm 1.03$ & $12.6 \pm 1.08$ & $13.2 \pm 1.09$ \\
\hline$\beta$-globulins & $12.5 \pm 1.12$ & $12.2 \pm 1.32$ & $12.6 \pm 1.08$ & $12.9 \pm 1.14$ & $13.9 \pm 1.09$ \\
\hline$\gamma$-globulins & $10.9 \pm 1.11$ & $11.4 \pm 1.31$ & $10.5 \pm 0.99$ & $12.3 \pm 1.47$ & $11.0 \pm 1.39$ \\
\hline $\begin{array}{l}\text { Alanine aminotransferase, } \\
\text { U/L }\end{array}$ & $23.00 \pm 0.58$ & $20.00 \pm 1.79$ & $22.00 \pm 1.65$ & $25.30 \pm 0.69 *$ & $29.00 \pm 1.76^{*}$ \\
\hline $\begin{array}{l}\text { Aspartate aminotransferase, } \\
\text { U/L }\end{array}$ & $45.00 \pm 2.03$ & $41.00 \pm 2.14$ & $43.00 \pm 1.74$ & $48.00 \pm 1.62$ & $52.00 \pm 1.59^{*}$ \\
\hline Glucose, mmol/l & $2.94 \pm 0.06$ & $2.76 \pm 0.09$ & $2.82 \pm 0.11$ & $3.01 \pm 0.21$ & $3.15 \pm 0.19$ \\
\hline Carotene, mg\% & $0.52 \pm 0.02$ & $0.50 \pm 0.03$ & $0.51 \pm 0.02$ & $0.54 \pm 0.07$ & $0.56 \pm 0.06$ \\
\hline Total calcium, mmol/L & $2.84 \pm 0.16$ & $2.82 \pm 0.21$ & $2.84 \pm 0.32$ & $2.91 \pm 0.28$ & $2.93 \pm 0.28$ \\
\hline $\begin{array}{l}\text { Inorganic phosphorus, } \\
\text { mmol/L }\end{array}$ & $1.67 \pm 0.16$ & $1.61 \pm 0.23$ & $1.64 \pm 0.38$ & $1.69 \pm 0.21$ & $1.71 \pm 0.41$ \\
\hline
\end{tabular}

Note. ${ }^{*} \mathrm{p}<0.05$ compared to group 1 .

$(\mathrm{p}<0.05)$, and aspartate aminotransferase - by $6.7 \%$ and $15.6 \%(\mathrm{p}<0.05)$, respectively.

The enzyme activity, such as aspartate aminotransferase, in fish of the experimental groups 2 and 3, which were fed compound feeds with a crude protein content of $44-46 \%$ approached the level of the control, while, compared to the analogs of experimental groups 4 and 5, there was some decrease in its activity.

The glucose content in blood of rainbow trout in the control group was 2.94 $\mathrm{mmol} / \mathrm{L}$, in blood of the experimental groups' fish - 2.76-3.15 mmol/L, however, different levels of crude protein in the feed had different effects on the value in fish of the experimental groups. The highest level of glucose was in blood of trout in the experimental group 5 and was $3.15 \mathrm{mmol} / \mathrm{L}$, which is by $7.1 \%$ more compared to the control and by $4.7-14.1 \%$ compared to the analogs in experimental groups 2-4.

Similar nature of the changes is observed in the serum carotene content of two-year-old rainbow trout. Its concentration in fish of the control group was $0.52 \mathrm{mg} \%$, while in fish of the experimental groups ranged from 0.50 to 0.56 $\mathrm{mg} \%$. There is no significant difference in this index between the control and experimental groups.

The rate of enzymatic reactions also depends on the concentration of minerals in the serum, in particular calcium and phosphorus. The results of experimental studies revealed an increase in the mineral status of rainbow trout blood when they consumed feed with the crude protein content of 50-52\%.

When assessing the indices of the trout's white blood (Table 4), no differences in the number of white blood cells 
depending on the action of paratypic factor were found. Differential white blood cell count in certain types of white blood is important for their detection. Changes in the conditions of fish keeping and feeding can increase the functions of some white blood cells and weaken them in others.

In particular, during experimental studies, it was found that changes in the feeding conditions of rainbow trout, contributed to some changes in the number of neutrophils in fish blood. Under the influence of the studied feed factor, their growth was found in trout of the experimental groups 4 and 5 . Thus, the number of neutrophils was the highest $(21.2 \%)$ in blood of fish in the experimental group 5, which were grown on compound feeds with increased to $52 \%$ levels of crude protein. At the same time, the reduction of crude protein levels to $44-46 \%$ (groups 2 and 3 ) contributed to a decrease in the number of neutrophils compared to the control.

The ratios of polymorphonuclear rods, lymphocytes and monocytes in blood of rainbow trout of the experimental groups, although slightly higher than those in the control, were within physiological fluctuations. When feeds with the crude protein content of $50 \%$ (exper- imental group 4) and $52 \%$ (experimental group 5) were used for feeding fish, the content of polymorphonuclear rods significantly increased and the content of lymphocytes and monocytes decreased compared to the control analogs.

Rearing of commercial trout on feed with a crude protein content of $52 \%$ (group 5) led to a reliable increase in the number of lymphocytes in blood, while the feeds with the crude protein level of $44 \%$ (group 2) and $46 \%$ (group 3), on the contrary, led to a slight decrease in their content.

For a more detailed assessment of the studied feed factor's influence on the functional state of the rainbow trout's body, we performed a study of the total blood lipids. In fish of the control group, its level was $3.66 \mathrm{mmol} / \mathrm{L}$; in analogs of the experimental groups, it was $3.52-4.09 \mathrm{mmol} / \mathrm{L}$. The highest level of total lipids $(4.09 \mathrm{mmol} / \mathrm{L})$ in blood of two-year-old rainbow trout was in experimental group 4, which were reared on compound feeds with a high (up to $50 \%$ ) levels of crude protein.

It was also found that with the decrease in the level of crude protein in the feed of two-year-old rainbow trout to $44-46 \%$ (experimental groups 2 and 3 ), there was a slight decrease in this index in blood plasma.

\section{Dynamics of changes in leukocyte formula and the total lipids content in blood of rainbow trout, $n=5$}

\begin{tabular}{|l|c|c|c|c|c|}
\hline \multirow{2}{*}{\multicolumn{1}{c|}{ Index }} & \multicolumn{5}{|c|}{ Fish group } \\
\cline { 2 - 6 } & 1st & 2nd & 3rd & 4th & 5th \\
\hline White blood cells, g/L & $22.9 \pm 1.09$ & $21.6 \pm 1.11$ & $22.0 \pm 1.12$ & $23.5 \pm 1.08$ & $24.0 \pm 1.21$ \\
\hline Neutrophils, \% & $19.9 \pm 1.12$ & $19.25 \pm 1.33$ & $19.42 \pm 1.47$ & $20.12 \pm 1.28$ & $21.20 \pm 1.39$ \\
\hline Polymorphonuclear, \% & $3.60 \pm 0.12$ & $3.71 \pm 0.41$ & $3.83 \pm 0.32$ & $4.20 \pm 0.65$ & $4.50 \pm 0.34^{*}$ \\
\hline Lymphocytes, \% & $60.45 \pm 2.06$ & $59.65 \pm 2.12$ & $60.14 \pm 2.47$ & $61.35 \pm 2.36$ & $67.12 \pm 2.03^{*}$ \\
\hline Monocytes, \% & $16.80 \pm 1.98$ & $16.05 \pm 2.03$ & $16.65 \pm 1.54$ & $17.40 \pm 1.71$ & $17.90 \pm 1.65$ \\
\hline Total lipids, mmol/L & $3.66 \pm 0.13$ & $3.52 \pm 0.31$ & $3.58 \pm 0.29$ & $4.09 \pm 0.09^{*}$ & $4.01 \pm 0.07^{*}$ \\
\hline
\end{tabular}

Note. ${ }^{*} \mathrm{p}<0.05$ compared to group 1 . 
Thus, the results of physiological and biochemical studies have shown that increasing the levels of protein nutrition in rainbow trout promotes better hematopoiesis, which leads to their high commercial qualities.

\section{Conclusions}

1. It was found that the number of white blood cells in blood of rainbow trout, which received compound feed with the protein content of $48 \%$ was $22.9 \mathrm{~g} / \mathrm{L}$, in blood of fish consuming feed with a protein content of $52 \%$, this figure was higher by $4.8 \%(\mathrm{p}<0.05)$.

2. Increase of crude protein in the production feed from 48 to $52 \%$ provides an increase in the total blood protein by $8.8 \%(\mathrm{p}<0.05)$.

3. It is proved that when using rainbow trout feed with the crude protein content of 50-52\%, the higher alanine aminotransferase activity by $10.0 \%$ $(\mathrm{p}<0.05)$ and by $26.1 \%(\mathrm{p}<0.05)$, respectively, and by $6.7 \%$ and $15.6 \%$ $(p<0.05)$ that of aspartate aminotransferase, is observed in blood of fish compared to fish that consumed feed with the protein level of $48 \%$.

4. The number of neutrophils was the largest and amounted to $21.2 \%$ in blood of fish reared on compound feeds with an increase to $52 \%$ level of crude protein. Reducing crude protein levels from $48 \%$ to $44-46$ $\%$ contributed to some reduction in neutrophils.

5. It was found that the total amount of blood lipids in two-year-old rainbow trout, which consumed feed with the protein content of $50-52 \%$, increases by $9.6-11.7 \%(\mathrm{p}<0.05)$ compared to those who were reared on compound feed with the protein level of $48 \%$.

\section{References}

1. Vlizlo, V. V., Fedoruk, R. S., Ratych, I. B. et al. (2012). Laboratorni metody doslidzhen y biolohii, tvarynnytstvi ta veterynarniy medytsyni [Laboratory study methods in biology, animal husbandry and veterinary medicine]. Dovidnyk za red. V. V. Vlizla. LVIV: SPOLOM.

2. Kanydev, A. N. (1985). Instruktsiya po razvedenyiu raduzhnoy foreli [Instructions for breeding rainbow trout]. Moscow: VNYYPRKh.

3. Kondrakhin, I. P., Arkhipov, A. V., Levchenko, V. I. et al. (2004). Metody veterinarnoy klinicheskoy laboratornoy diagnostiki: spravochnik pod redactsiey I.P. Kondrakhina [Methods of veterinary clinical laboratory diagnostics: reference book]. Moscow: Kolos.

4. Plokhynskyi, N. A. (1969). Rukovodstvo po byometrii dlia zootekhnykov [Biometrics guide for livestock technicians]. Moscow: Kolos.

5. SOU-05.01-37-385:2006. (2006). Voda rybohospodarskykh pidpryiemstv. Zahalni vymohy ta normy [Water of fishery enterprises. General requirements and norms]. Kyiv: Ministerstvo ahrarnoyi polityky Ukrainy.

6. Sherman, I. M., Hrynzhevskyi, M. V., \& Zheltov, Yu. O. (2002). Naukove obhruntuvannia ratsionalnoyi hodivli ryb: uchebnoye posobiye. Vyshcha osvita. [Scientific substantiation of efficient fish feeding: the manual. Higher education.

7. Karabulut, H. A., \& Yandi, N. M. (2010). Aras effects of different feed and temperature conditions on growth, meat yield, survival rate, feed conversion ratio and condition factor in rainbow trout (Oncorhynchus mykiss) fingerlings. Journal of Animal and Veterinary Advances. 9 (22). 2818-2823.

8. Kim, J. D., \& Kaushik, S. J. (1992). Contribution of digestible energy from growth of rainbow trout (Oncorhynchus mykiss). Aquaculture. 106(2). 161-169. 
9. Mahmud, S., Chakraborty, C., \& Das, M. (1996). Performance of rainbow trout (Oncorhynchus mykiss) fed on different dietary protein with fixed energy. Asian-Australasian Journal of Animal Sciences. 9(1). 31-35.

10. Ullah-Khan, K., Tellechea-Rodrigues, A., Menegasso-Mansano, C. F., Queiroz, D.
M. D. A., Kazue-Sakomura, N., Romaneli, R. D. S., \& Kochenborger-Fernandes, J. B. (2019). Dietary protein quality and proper protein to energy ratios: a bioeconomic approach in aquaculture feeding practices. Latin American journal of aquatic research. 47(2). 232-239.

\section{В. М. КОНДратюК (2021). ГЕМАТОЛОГІЧНІ ТА БІОХІМІЧНІ ПОКАЗНИКИ КРОВІ РАЙДУЖНОЇ ФОРЕЛІ ЗАЛЕЖНО ВІД РІВНЯ ПРОТЕЇНУ У КОМБІКОРМАХ.}

ANIMAL SCIENCE AND FOOD TECHNOLOGY, 12(1): 5-13.

https://doi.org/10.31548/animal2021.01.005.

Анотація. У статті досліджено вплив використання повнораціонних комбікормів із різним рівнем протеїну на гематологічні та біохімічні показники крові форелі. Метою досліду передбачалося встановити вплив різних рівнів протеїнового живлення товарної райдужної форелі на гематологічні та біохімічні показники їхньої крові. Для цього за методом аналогів було сформовано п'ять піддослідних груп. Дослід тривав 210 діб та поділявся на два періоди: зрівняльний (10 діб) та основний (200 діб). У зрівняльний період раціон годівлі був однаковим для риб контрольної та експериментальних груп. В основний період рівень протеїну в експериментальних комбікормах для різних піддослідних груп форелі коливався від 44 до 52 \% у 1 кг. Встановлено, що різні рівні протеїнового живлення райдужної форелі не спричиняють суттєвих змін у морфологічному складі крові. Доведено, що вирощування форелі на комбікормах із вмістом сирого протеїну 50 \% та 52 \% сприяє збільшенню в крові кількості еритроцитів, гемоглобіну, лейкоцитів та фагоцитарної активності. Використання в годівлі риб раціонів зі зниженим вмістом сирого протеїну (44 \% та 46 \%) призводить до зменшення морфологічних компонентів крові. У результаті досліджень фагоцитарної активності нейтрофілів у крові риб виявлено незначне їх зростання під дією досліджуваного фактора. Аналізом отриманих результатів встановлено, що зі збільшенням рівнів сирого протеїну в раціонах райдужної форелі, концентрація загального білку та його фракцій в сироватиі крові підвищувалась. Відповідно, кількість загального білку в крові риб контрольної групи становила 60,0 г/л, у дослідних груп - була в межах 59,6-65,3 г/л. Підвищення рівня протеїнового живлення райдужної форелі 4 та 5 дослідних груп викликало зростання кількості альбумінів, 6-глобулінів та ү-глобулінів, порівняно з аналогічними показниками риб контрольної групи. У результаті проведених експериментальних досліджень встановлено підвищення мінерального статусу крові райдужної форелі за ії годівлі комбікормами з вмістом сирого протеїну на рівні 50-52 \%. Під час очінки показників білої крові форелі відмінностей в кількості лейкоцитів не виявлено.

Ключові слова: товарна райдужна форель, годівля риб, комбікорми, протеїн, гематологічні показники, лейкоцитарна формула, біохімічні показники крові. 